\title{
Refuges from predation and the persistence of estuarine clam populations
}

\author{
G. A. Skilleter* \\ Institute of Marine Sciences, University of North Carolina at Chapel Hill, Morehead City, North Carolina 28557, USA
}

\begin{abstract}
Densities of adult infaunal clams Macoma balthica and Mya arenaria in mesohaline sections of Pamlico Sound, North Carolina, USA, declined rapidly between April and June 1991 and 1992, except in places where there was abundant shell material on the sediment or large densities of the mactrid bivalve Rangia cuneata. Survivorship of $M$. balthica and $M$. arenaria was examined experimentally in $1 \mathrm{~m}^{2}$ plots containing different types of habitat: widgeon grass Ruppia maritima, live $R$. cuneata, 'artificial' $R$. cuneata, shell valves of $R$. cuneata and clean sediments to determine whether these structures provided a refuge from predation for the clams. $M$. balthica and $M$. arenaria obtained a substantial refuge from predation by crabs when living in patches containing $R$. cuneata. Neither species obtained a refuge from predation when in beds of widgeon grass. There were 2 surprising results in these experiments. First, survivorship of the clams was significantly reduced in patches containing both seagrass and $R$. cuneata compared with patches of only $R$. cuneata. Second, survivorship was significantly less in patches of live $R$. cuneata than in patches of 'sham' (artificial) clams or equal numbers of shell valves. Two alternative, but not necessarily exclusive, explanations are offered for these results. (1) Subsurface rhizomes of widgeon grass may reduce the depth to which clams are able to burrow into the substratum leaving them more susceptible to predation by digging crabs. (2) Increased availability of alternative prey in patches of widgeon grass causes predators to spend more time foraging in these patches and, by chance alone, they capture more clams. Alternatively, predators spend more time in the patches with widgeon grass because they obtain a partial refuge from their own predators. The occurrence of a refuge from predation for $M$. arenaria and $M$. balthica living with $R$. cuneata is a striking example of an associational defense between potentially competing species. Associational defenses such as this may be a common structuring force in soft-sediment systems and future work may help in producing a more synthetic understanding of their importance in aquatic systems.
\end{abstract}

KEY WORDS: Refuges Predation - Estuarine B Bivalves S Seagrass Associational defense - Macoma balthica Mya arenaria

\section{INTRODUCTION}

Ecologists have long recognised the importance of spatial heterogeneity when considering interactions between predators and their prey. One mechanism through which spatial heterogeneity acts to modify predator-prey interactions is by the provision of partial refuges wherein prey can escape the activities of their predators (Murdoch \& Oaten 1975). Refuges from predation are very important in explaining the persistence

\footnotetext{
- Present address: Institute of Marine Ecology, Biological Sciences A11, University of Sydney, NSW 2006, Australia
}

of some species despite intense levels of predation (Huffaker 1958, Connell 1970, Caswell 1978).

In marine and freshwater environments, the best known example of the importance of spatial heterogeneity is the role of emergent macrophytes in providing a partial refuge from predation. Extensive work in freshwater systems has shown that as habitat complexity increases, levels of predation tend to decrease (e.g. Crowder \& Cooper 1982, Savino \& Stein 1982, Gilinsky 1984, Gotceitas \& Colgan 1989). Similarly, in the marine environment emergent macrophytes reduce predation in rocky intertidal habitats (Suchanek 1978), subtidal kelp beds (Bernstein \& Jung 1979, Dayton 1985, Ebeling \& Laur 1985), salt marshes (Vince et al. 
1976, Minello \& Zimmerman 1983) and in seagrass beds (Coen et al. 1981, Heck \& Thoman 1981, Stoner 1982, Summerson \& Peterson 1984, Leber 1985, Irlandi \& Peterson 1991). Other emergent structures, such as polychaete worm tubes, are also thought to be important in providing refuges for meiofauna (Hicks \& Coull 1983, Marinelli \& Coull 1987) and macrofauna (Woodin 1978).

Emergent structures are, however, not the only form of refuge that occurs in these environments. In softsediment habitats, the below-ground component of seagrass beds, the extensive mats of rhizomes and roots, has been implicated in reducing mortality of infauna (Reise 1977, 1978, Virnstein 1977, Peterson 1982, Summerson \& Peterson 1984, Capehart \& Hackney 1989). In rocky intertidal regions, the presence of pits and crevices in the rocky substratum (e.g. Kohn \& Leviten 1976, Lubchenco et al. 1984, McGuinness \& Underwood 1986) has been shown to increase prey abundance and diversity. Other structures lying on the surface of sediment, or buried below the sediment, may also furnish a physical structure modifying the habitat and providing a refuge for prey against predators. These can include cobbles and rocks (Stein \& Magnuson 1976, Barshaw \& Lavalli 1988), shell and gravel material (Arnold 1984, Dumbauld et al. 1993 Fernandez et al. 1993) or coarse woody debris (Everett \& Ruiz 1993 and references therein).

In Chesapeake Bay, USA, 2 common and abundant species of soft-sediment infauna, the clams Mya arenaria and Macoma balthica, show striking seasonal changes in their abundance as a function of changes in the abundance of their principle predator, the blue crab Callinectes sapidus (Hines et al. 1990, Eggleston et al. 1992a). Population cycles of $M$. arenaria and $M$. balthica are characterised by large increases in abundance in winter and early spring following spawning and settlement followed by a rapid reduction during the following summer (Blundon \& Kennedy 1982a, Hines et al. 1990, Eggleston et al. 1992a). Small densities of both species are, however, able to persist in the field by taking advantage of a refuge in burial depth within the substratum (Hines \& Comtois 1985) and density-dependent functional responses of blue crabs (Lipcius \& Hines 1986, Eggleston et al. 1992a). The role of other potential refuges, such as seagrasses or shell material, has not been investigated for either species, although Blundon \& Kennedy (1982a) found that artificial plants did provide $M$. arenaria a partial refuge from crabs in laboratory experiments.

Although both Mya arenaria and Macoma balthica are also common in mesohaline sections of Pamlico Sound, North Carolina, USA (Tenore 1972, Homziak 1985), very little is known about the importance of predation or the role of potential refuges in structuring and controlling populations of either species in these waters. Seagrasses and other aquatic macrophytes are common in nearshore habitats of Pamlico Sound (Ferguson et al. 1988, pers. obs.) and may provide a refuge for clams from predation by abundant blue crabs. In parts of Pamlico Sound, $M$. arenaria and $M$. balthica also co-occur with the large mactrid bivalve Rangia cuneata (Tenore 1972), the latter often reaching extremely high densities (>100 $\mathrm{m}^{2}$; pers. obs.). $R$. cuneata is relatively immune to predation by blue crabs, a result of its strong shell valves and globose shape (Blundon \& Kennedy 1982b). R. cuneata buries itself just beneath the surface of the sediment whereas both $M$. arenaria and $M$. balthica burrow relatively deep (Hines \& Comtois 1985). By living beneath a layer of $R$. cuneata, these species may obtain some protection from the activities of blue crabs. Here, I describe the results of experiments which investigate the importance of seagrasses and $R$. cuneata as refuges from predation for $M$. arenaria and $M$. balthica in mesohaline estuarine waters in Norı Carolina.

\section{MATERIALS AND METHODS}

Sampling methods. I sampled different sites (Fig. 1) in mesohaline sections of North Carolina estuaries in 1991 and 1992 to determine the abundance of Mya arenaria and Macoma balthica before (March-April) and after (July) the seasonal increase in activity of blue crabs (e.g. Peterson 1990) to evaluate whether densities of each species showed the rapid decline characteristic of Chesapeake Bay studies (references above). Some of these data formed part of a larger survey on the distribution of $M$. arenaria in North Carolina waters (C. H. Peterson unpubl.)

At each site, I collected 20 replicate cores to a depth of $20 \mathrm{~cm}$ using either a hand-held corer $\left(0.0078 \mathrm{~m}^{2}\right.$ area $)$ or a suction dredge $\left(0.25 \mathrm{~m}^{2}\right)$. Samples collected with the hand corer were standardised to an area of $0.25 \mathrm{~m}^{2}$ for comparison with those from the suction dredge Samples were sieved through a $1 \mathrm{~mm}$ mesh in the field and the number of Mya arenaria and Macoma balthica recorded. In 1992 at sites on the Pamlico River, I also recorded the number of live and number of dead shell valves of Rangia cuneata in $30 \times 0.25 \mathrm{~m}^{2}$ cores because at one site this species was particularly abundant, as was $M$. balthica, and there appeared to be a positive correlation between the abundances of the 2 species.

Field experiments. All Macoma balthica for use in experiments were collected from Big Creek, South River (1991) or from Pamlico River, south of Indian Island (1992). Clams were removed from the sediment using either the hand-held corer or the suction dredge. Only undamaged specimens were kept for experi- 


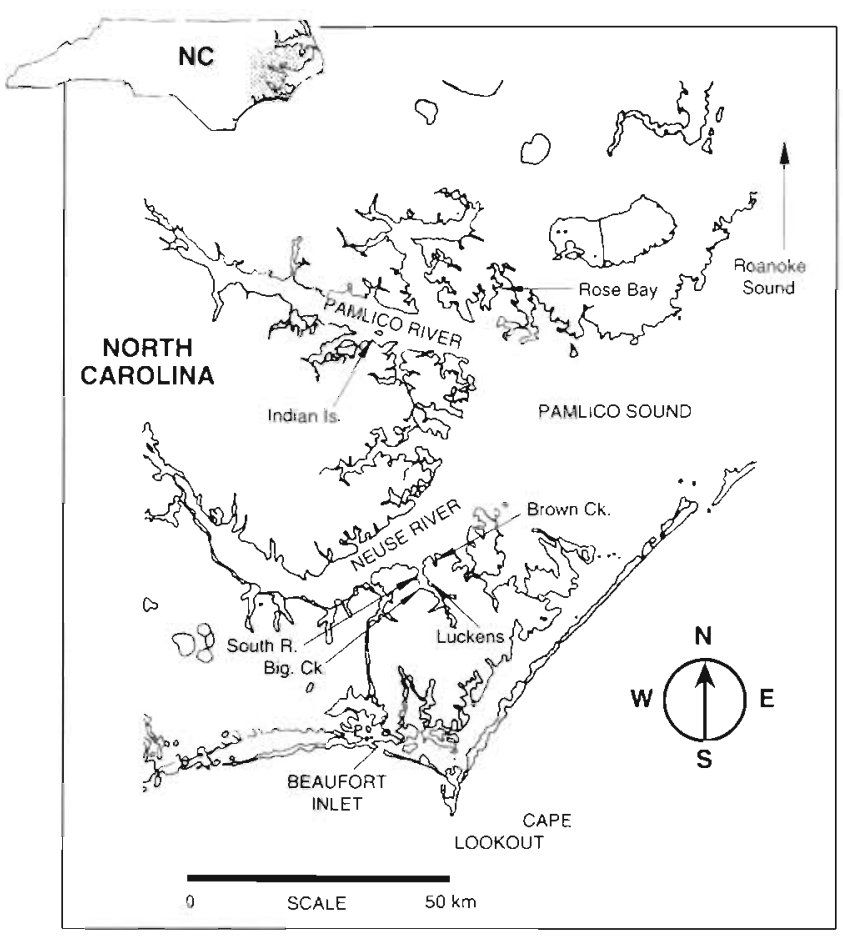

Fig. 1. Map of North Carolina (USA) showing study sites used for sampling and experiments

ments. Clams were always collected on the day previous to being utilised in an experiment and were maintained overnight in aerated seawater taken from the collection site.

Mya arenaria were obtained from a clam hatchery in Atlantic, North Carolina, on Core Sound. All clams were from natural set in the hatchery raceways and were collected in May at a size of approximately 10 to $25 \mathrm{~mm}$ shell length. They were initially maintained in flow-through plastic aquaria using unfiltered seawater pumped from Bogue Sound. Later they were transferred to small $(30 \times 30 \times 15 \mathrm{~cm}$ high) cages in South River until they were needed.

In experiments, clams were inserted into the sediment in $1 \mathrm{~m}^{2}$ plots, oriented with the foot downwards, until the anterior end of the shell was about $2 \mathrm{~cm}$ below the surface of the substratum. In patches of widgeon grass Ruppia maritima, this depth was below the shallow mat of rhizomes. Clams were allowed to bury deeper of their own accord. Sediments were rarely more than $20 \mathrm{~cm}$ deep in the shallow regions of South River and Big Creek where the experiments were done. Below this was an impenetrable clay hardpan layer. Plots were immediately covered with nylon mesh tops (mesh size $5 \mathrm{~mm}$ ), weighted on the edges, to protect clams from predators while they buried further $(24 \mathrm{~h})$. These mesh covers had proven to be effective in reducing predation by blue crabs in earlier trials (C. $\mathrm{H}$. Peterson pers. comm.).
General experimental methods. I manipulated the availability of 4 different naturally occurring types of habitat in order to determine their relative effectiveness in providing a refuge from predation for Mya arenaria and Macoma balthica. The 4 types of habitat used were bare sediment, widgeon grass Ruppia maritima, beds of the freshwater clam Rangia cuneata and sediments containing shell material (single valves of $R$. cuneata).

Survivorship of Mya arenaria and Macoma balthica was examined in $1 \mathrm{~m}^{2}$ plots containing one of the different habitats at sites in South River and Brown Creek (Fig. 1) during spring-summer of 1991 and 1992, the period when blue crabs Callinectes sapidus were active in these sections of the estuary (pers. obs.). The following treatments were used in field experiments: bare sediment; widgeon grass; sediment plus 50 Rangia cuneata; widgeon grass plus $50 R$. cuneata; sediment plus 50 'sham' $R$. cuneata; sediment plus $100 R$. cuneata shell valves. Bare sediment refers to substratum that was devoid of above- or below-ground seagrass material (Ruppia maritima) and had no large $(>1 \mathrm{~cm}$ ) shell fragments present. A density of $50 R$. cuneata per $\mathrm{m}^{2}$ was approximately mid-range in the densities that occurred naturally in the field (pers. obs.).

I used 'sham' Rangia cuneata to determine whether any effect on survivorship provided by live $R$. cuneata as compared with bare sediment was related to some feature of the live animal (e.g. active movement within the substratum) rather than just the physical presence of the closed valves in the substratum. Sham $R$. cuneata were made by cementing together the valves of recently killed clams using a sand-based mortar. The sham clams were left in running seawater for $1 \mathrm{wk}$ to ensure that they would hold together before being used in the experiments. Dead clams were of the same size range as the live clams used in the experiments. The sham clams occupied the same volume in the sediments as live animals. Similarly, I used shell valves $(100$ valves $=50$ clams $)$ to determine whether any refuge value of this habitat was related to shells of $R$. cuneata occupying their natural living position in the sediment or was due merely to the presence of physical structure in the sediment.

Plots were selected haphazardly in areas with a mixture of widgeon grass and bare sand. The patchy distribution of the grass in these habitats enabled me to intersperse treatments rather than having them established in different sites, avoiding confounding the effects of grass with those due to spatial variability. Each $1 \mathrm{~m}^{2}$ plot was marked in the corners with a metal rod driven into the substratum. For those treatments with live or sham Rangia cuneata, I pushed the clams into the sediment haphazardly, anterior end upright, until the anterior margin was approximately $1 \mathrm{~cm}$ below the surface of the substratum, their natural 
living position. For plots already containing widgeon grass, I was careful to avoid disturbing too much of the grass material; the rhizome mat of widgeon grass is not very thick and was easily penetrated. For treatments with shell material ( $R$. cuneata shell valves), I pushed 100 shell valves from $R$. cuneata into the sediment in haphazard positions until they were all buried below the surface.

Before I set up any plots, I sampled the sediments at each site to determine whether adults of Mya arenaria or Macoma balthica were present at the time, and if so, to estimate their densities. At each site, I took five $0.25 \mathrm{~m}^{2}$ cores at up to $20 \mathrm{~cm}$ depth and sorted them for adult $M$. arenaria and $M$. balthica. At least 2 samples at each site were collected from areas with seagrass. Densities were never more than 1 or 2 clams $\mathrm{m}^{-2}$ at the sites used for experiments so it was unlikely that estimates of survivorship in experimental plots were unduly biased by pre-existing clams.

Expt 1: pilot experiments with Ruppia maritima. In 1991, I examined the refuge value of $R$. maritima for Mya arenaria and Macoma balthica at different sites in South River and Brown Creek. In May and June 1991, 2 separate pilot experiments ( 1 for $M$. arenaria, 1 for $M$. balthica) were used to determine the length of time that field experiments should run. For unbiased comparisons of survivorship among treatments, it is essential that the mean density of survivors in all treatments be greater than zero at the end of the experiment. A secondary aim here was to determine whether the mesh tops used to cover plots were effective in preventing access of large predators (e.g. blue crabs) to the buried clams and would serve to maintain plots free of predation.

For each experiment, I marked out 36 plots of $1 \mathrm{~m}^{2}$, 18 in bare sediment and 18 in widgeon grass. I haphazardly assigned half as predator-exclusion plots (covered), the other half as open plots. The experiment was sampled 3 times, after 2, 4 and $7 \mathrm{~d}$, with 3 different replicate plots for each treatment (grass: open and predator-exclusion; bare sediment: open and predatorexclusion) sampled on each occasion. A limitation on the available number of mesh tops meant I set up the $7 \mathrm{~d}$ treatment sequentially, after all plots from the previous $2 \mathrm{~d}$ had been sampled.

Into each plot, I added 50 clams, either Macoma balthica (mean length $\pm \mathrm{SE}=23.83 \pm 0.20 \mathrm{~mm} ; \mathrm{n}=50$ ) or Mya arenaria (mean length $\pm \mathrm{SE}=26.21 \pm 0.34 \mathrm{~mm}$; $\mathrm{n}=50$ ), then immediately covered all plots with mesh tops. After $24 \mathrm{~h}$ I removed the tops of those plots designated as open, and checked the mesh tops were secure on predator-exclusion plots. At the end of the appropriate period of time, I sampled each plot by digging by hand to a depth of $20 \mathrm{~cm}$ all the sediment in the $1 \mathrm{~m}^{2}$ area and passing it through a $3 \mathrm{~mm}$ sieve to determine the number of clams still alive and hence the proportional survivorship through time in the 2 different habitats. Loss of specimens in the control plots represented mortality or migration of clams unrelated to predation by large ( $>1 \mathrm{~mm}$ ) predators. All Ruppia maritima in the grass plots was placed in a labelled bag for later determination of total combined biomass of rhizome and shoot material in the vegetated plots. In the lab, $R$. maritima samples were cleaned of adhering shell and sediment then dried at $70^{\circ} \mathrm{C}$ for approximately $10 \mathrm{~d}$. Dry weights of total grass material (rhizome plus shoot material) was determined to the nearest $0.1 \mathrm{~g}$

I analysed the survivorship data, separately for each species, using a 3-factor ANOVA, factors Time $(2,4$ and $7 \mathrm{~d}$ ), Predator (plus or minus) and Habitat (sand or seagrass) fixed, on arcsine-transformed proportions (Underwood 1981). Variances were homoscedastic after this transformation (Cochran's test; $\mathrm{p}>0.05$ ).

Expt 2: effects of Ruppia maritima at different sites. In September 1991, I again examined the value of $R$. maritima as a refuge against predation for Mya arenaria and Macoma balthica, but this time used sites in Brown Creek and South River which had different amounts of seagrass cover to determine whether results obtained in previous experiments were related to the relatively small biomass of grass present at the time. At each site, I marked out 16 plots of $1 \mathrm{~m}^{2}, 8$ in bare sediment and 8 in widgeon grass, and haphazardly assigned half as controls (covered) and half as open plots. There were 4 replicate plots for each of the 4 treatments (grass: open and control; bare sediment open and control). The site in Brown Creek had thick patches of $R$. maritima which stood up to $20 \mathrm{~cm}$ off the bottom whereas the site in South River (Luckens Fig. 1) had grass which was only about 5 to $6 \mathrm{~cm}$ long

For the first run of this experiment, I added $50 \mathrm{Mya}$ arenaria (mean length $\pm \mathrm{SE}=25.58 \pm 0.23 \mathrm{~mm} ; \mathrm{n}=50$ ) into each plot then immediately covered all plots with a mesh top. To ensure that plots at each site were left exposed for equal amounts of time I started the experiment with a $24 \mathrm{~h}$ delay between sites: the time taken to sample all plots at a single site prevented both sites being sampled on a single day. After $24 \mathrm{~h}$ I removed the tops from the open plots. These plots were then left for $7 \mathrm{~d}$, after which I sampled all plots in the manner described above, again putting all Ruppia maritima into labelled bags for determination of total biomass.

I then marked out another 16 plots of $1 \mathrm{~m}^{2}$ in the same design as before but this time ensuring that vegetated plots were at least $2 \mathrm{~m}$ from any plots previously sampled (and now devoid of grass material). To each plot I added 50 Macoma balthica (mean length \pm $\mathrm{SE}=28.89 \pm 0.24 \mathrm{~mm} ; \mathrm{n}=50$ ) and repeated the experiment, again leaving open plots exposed for $7 \mathrm{~d}$. 
I analysed the data on survivorship for each species with a 3-factor ANOVA, factors Site random, Predator and Habitat fixed, on arcsine-transformed proportions (Underwood 1981). Even though the experiment started at different times ( $24 \mathrm{~h}$ apart) for the 2 sites I analysed the data in a single analysis because I wanted to determine if survivorship was consistent among treatments at both sites.

Expt 3: effects of Rangia cuneata on Mya arenaria. In July 1992, I examined the survivorship of $M$. arenaria in habitats containing live $R$. cuneata compared with bare sediment or seagrass Ruppia maritima at 2 sites on South River. At each site, I marked 24 plots of $1 \mathrm{~m}^{2}$, 12 in bare sediment and 12 in widgeon grass, and haphazardly assigned half as controls (covered) and half as open plots. Into 6 each of the bare sediment and grass plots I added $50 \mathrm{R}$. cuneata (mean length $\pm \mathrm{SE}=$ $37.78 \pm 0.56 ; n=50$ ). There were 3 replicate plots for each of the 8 treatments (open and control for: bare sediment, widgeon grass, sediment $+50 R$. cuneata, and widgeon grass $+50 R$. cuneata). I then added $50 \mathrm{M}$. arenaria (mean length $\pm \mathrm{SE}=22.43 \pm 0.29 \mathrm{~mm} ; \mathrm{n}=50$ ) to each plot and covered them with mesh tops for $24 \mathrm{~h}$ while the clams established themselves in the sediment. At this time I removed the tops from all open plots and left the experiment for $7 \mathrm{~d}$. To ensure that plots at each site were left exposed for equal amounts of time I started the experiment with a 24 h delay between sites.

At the end of the experiments all plots were sampled to a depth of $20 \mathrm{~cm}$ using the suction dredge to recover live Mya arenaria. I retained the grass for later determination of biomass from all vegetated plots. The data on survivorship in each habitat were analysed with a 3-factor ANOVA, factors Site random, Predator and Habitat fixed, on arcsine-transformed proportions. Variances were homoscedastic after this transformation (Cochran's test; $\mathrm{p}>0.05$ ).

Expt 4: effects of Rangia cuneata and shell on Macoma balthica. In September 1992, I examined the survivorship of $M$. balthica in habitats containing live $R$. cuneata, sham $R$. cuneata and dead shell valves of $R$. cuneata compared with bare sediment at a single site in South River. Only a single site could be examined because strong storms washed away or buried the mesh covers over control plots at the second site. Also, these storms coincided with the rapid decline in abundance of Ruppia maritima from shallow sections of South River so no grass treatments could be included in this experiment.

I marked 24 plots of $1 \mathrm{~m}^{2}$ in bare sediment, away from the few patches of widgeon grass that still remained in the shallows. Into each of 6 plots 3 replicates haphazardly designated as controls, 3 as open plots), I added 50 live Rangia cuneata (mean length $\pm \mathrm{SE}=38.48 \pm 0.61 ; \mathrm{n}=50), 50$ sham $R$. cuneata and 100 shell valves of $R$. cuneata, followed by $50 \mathrm{Ma}$ coma balthica (mean length $\pm \mathrm{SE}=28.84 \pm 0.26 \mathrm{~mm}$; $\mathrm{n}=50$ ). All plots were covered by mesh tops for $24 \mathrm{~h}$, then open plots were left exposed for $7 \mathrm{~d}$. At the end of the experiment I sampled each plot to a depth of $20 \mathrm{~cm}$ with the suction dredge to determine the number of clams surviving in each habitat. These data were analysed with a 2-factor ANOVA with factors Predator and Habitat fixed, on arcsine-transformed proportions.

\section{RESULTS}

Densities of Mya arenaria (Fig. 2) and Macoma balthica (Fig. 3) showed a rapid decline between April (early spring) and July (summer) in North Carolina estuaries. In Rose Bay and Roanoke Sound (Fig. 1), 2 places where $M$. arenaria were initially abundant, the clams were undetectable by July (Fig. 2). A similarly large decline in density was observed for $M$. balthica at all but 2 sites sampled (compare Fig. 3A to F with Fig. 3G, H). At a single site in Big Creek, South River and 1 site in the Pamlico River, densities of $M$. balthica increased rather than decreased between April and July. The site in Big Creek was adjacent to a North Carolina Division of Marine Fisheries shell stockpile characterised by large quantities of oyster and scallop shell lying on and in the sediment. The site in Pamlico River, south of Indian Island, was an area with dense stands of Ruppia maritima and high densities of live Rangia cuneata.

At this latter site, the densities of Macoma balthica and Rangia cuneata were positively correlated in the $0.25 \mathrm{~m}^{2}$ cores $\left(\mathrm{r}^{2}=0.27 ; \mathrm{p}<0.01 ; \mathrm{Fig}\right.$. 4). When the total number of $R$. cuneata, including dead shells, was incorporated this positive correlation increased substantially to an $\mathrm{r}^{2}$ value of 0.63 (Fig. 4).

\section{Expt 1: pilot experiments with Ruppia maritima}

In the pilot experiments, survivorship of Mya arenaria and Macoma balthica was not significantly enhanced in
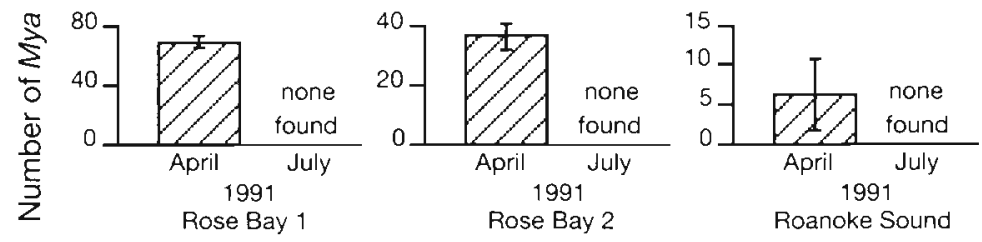

Fig. 2. Mean number ( $\pm \mathrm{SE}$ ) of Mya arenaria per $0.25 \mathrm{~m}^{2}$ area at 3 sites in Pamlico Sound in April and July 1991. None found: samples were collected but densities were zero 


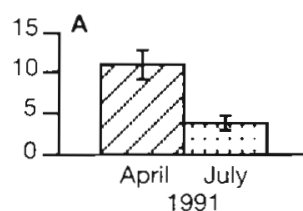

Rose Bay 2
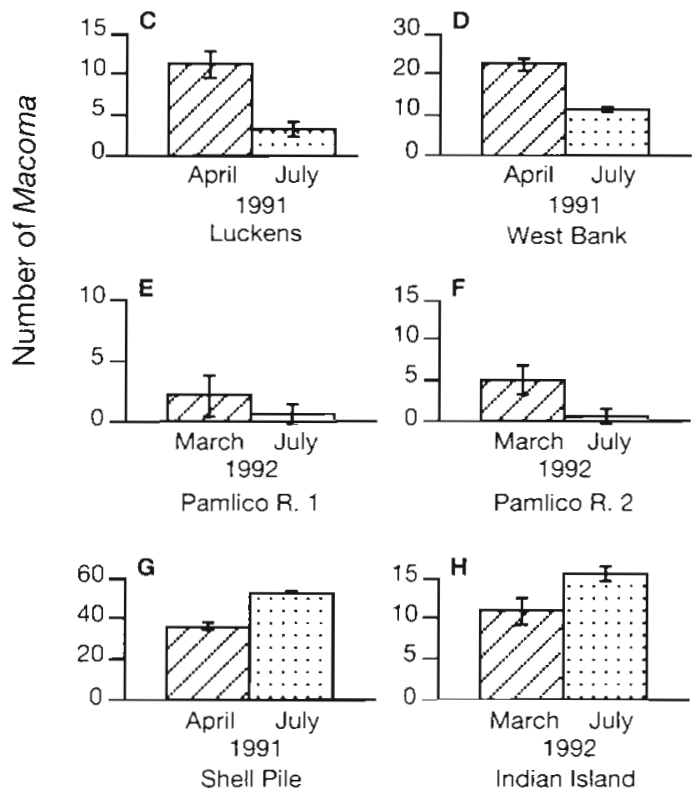

Fig. 3. Mean number ( \pm SE) of Macoma balthica per $0.25 \mathrm{~m}^{2}$ area at 8 sites in Pamlico Sound, Pamlico River and South River in March-April and July 1991 and 1992

plots with seagrass compared with bare sediment (ANOVA; Table 1, Fig. 5). After only $7 d_{\text {, survivorship of }}$ each species was between 10 and $22 \%$ in open plots in both habitats whereas in predator-exclusion plots survivorship was between 80 and $95 \%$ (Fig. 5). Although there was a significant interaction between Predator and Habitat (Table 1), Student-Newman-Keuls (SNK) tests were unable to distinguish differences between the effects of predators in the 2 habitats. The mean $( \pm \mathrm{SE}$ )
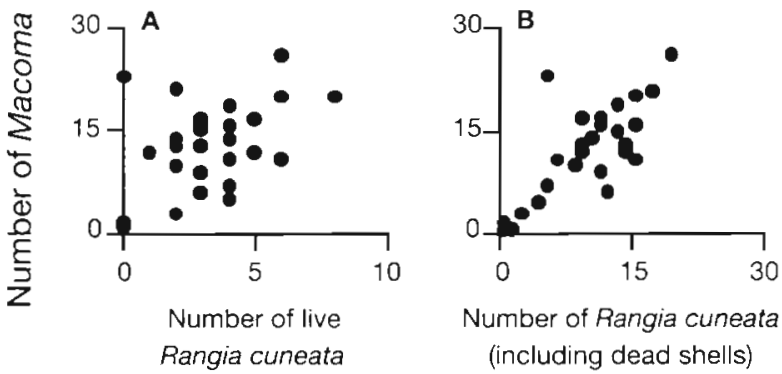

Fig. 4. Relationship between the density of Macoma balthica and (A) the density of live Rangia cuneata and (B) all $R$. cuneata including dead shells at the site south of Indian island on the Pamlico River

dry biomass of Ruppia maritima in the vegetated plots was $34.65 \pm 2.50 \mathrm{~g} \mathrm{~m}^{-2}$ for the experiment with $M$. arenaria and $48.09 \pm 2.06 \mathrm{~g} \mathrm{~m}^{-2}$ for the experiment with $M$. balthica ( $\mathrm{n}=12$ for each). None of the bare sediment plots had any $R$. maritima in them.

\section{Expt 2: effects of Ruppia maritima at different sites}

In the second set of experiments with seagrass, there was again no significant increase in survivorship of Mya arenaria or Macoma balthica in seagrass plots over those in bare sediment at either site (ANOVA; Table 2, Fig. 6). This was despite the fact that in Brown Creek the biomass of grass had more than doubled on this occasion compared with in May/June and was over 3 times the biomass at Luckens in South River. Survivorship of each species was still less than $15 \%$ in each habitat type after only $7 \mathrm{~d}$ predation. The significant 3-way interaction ( $\mathrm{S} \times \mathrm{P} \times \mathrm{H}_{i}$ Table 2$)$ in survivorship of $M$. balthica was a result of there being significantly greater survivorship of clams exposed to predators in Ruppia maritima at Brown Creek than at Luckens (SNK tests) although none of the other treatments differed between the 2 sites (Fig. 6).

Table 1. Analysis of mean survivorship of Mya arenaria and Macoma balthica in 2 different Habitats (bare sediment and Ruppia maritima) after 2,4 and 7 d exposure (Time) with treatments plus or minus Predators (data transformed to arcsine $\sqrt{\bar{x}} ; n=3$ plots) In this and all subsequent tables: $p<0.05 ; \cdots p<0.01 ; \cdots p<0.001 ;$ ns: not significant $(p>0.05)$

\begin{tabular}{|c|c|c|c|c|c|c|c|}
\hline \multirow{2}{*}{$\begin{array}{l}\text { Source of } \\
\text { variance }\end{array}$} & \multirow[b]{2}{*}{$d f$} & \multicolumn{3}{|c|}{ Mya arenaria } & \multicolumn{3}{|c|}{ Macoma balthica } \\
\hline & & MS & $F$ & $\mathrm{p}$ & MS & $F$ & $p$ \\
\hline Time $(\mathrm{T})$ & 2 & 934.32 & 41.55 & $\cdots$ & 358.75 & 14.25 & $\cdots$ \\
\hline Predator (P) & 1 & 10516.90 & 467.69 & $\cdots$ & 8618.42 & 342.23 & $\cdots$ \\
\hline Habitat $(\mathrm{H})$ & 1 & 30.27 & 1.35 & ns & 4.45 & 0.18 & ns \\
\hline $\mathrm{T} \times \mathrm{P}$ & 2 & 981.49 & 43.65 & $\cdots$ & 538.90 & 21.40 & $\cdots$ \\
\hline $\mathrm{T} \times \mathrm{H}$ & 2 & 34.10 & 1.52 & ns & 26.03 & 1.03 & ns \\
\hline $\mathrm{P} \times \mathrm{H}$ & 1 & 104.69 & 4.66 & $\cdot$ & 107.56 & 4.27 & $\cdot$ \\
\hline $\mathrm{T} \times \mathrm{P} \times \mathrm{H}$ & 2 & 33.87 & 1.51 & ns & 16.12 & 0.64 & $\mathrm{~ns}$ \\
\hline Residual & 24 & 22.49 & & & 25.18 & & \\
\hline
\end{tabular}




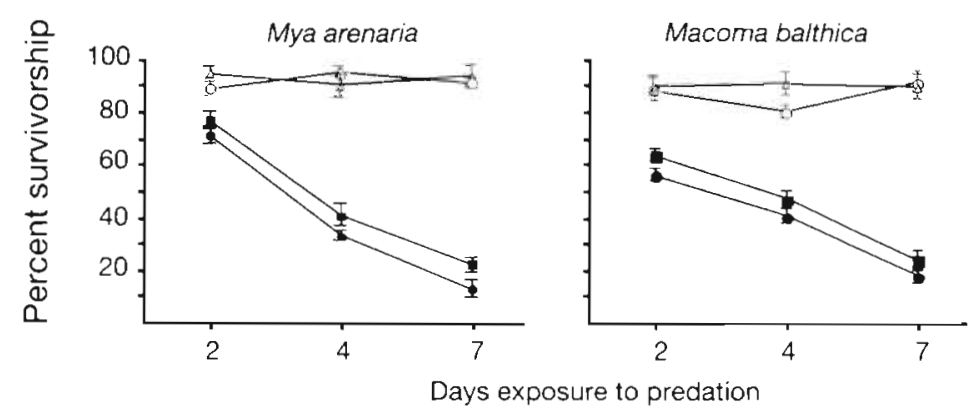

$\Delta$ sediment-exclusion

- sediment-open
- Ruppia-exclusion

- Ruppia-open

Fig. 5. Mean ( $\pm \mathrm{SE}) \%$ survivorship of Mya arenaria and Macoma balthica in plots of bare sediment and seagrass Ruppia maritima over $7 \mathrm{~d}$ in Brown Creek

\section{Expt 3: effects of Rangia cuneata on Mya arenaria}

In July 1992, survivorship of Mya arenaria in predator-exclusion plots was between 85 and $100 \%$ except in a single vegetated plot at the Luckens site. In this plot, only 27 clams were recovered (54\%), Given the poor survivorship in this plot compared with the other 23 predator-exclusion plots, I decided that the mesh top had been breached by a predator and I discarded this datum, replacing it with the mean of the other 2 replicates for that treatment. Accordingly, the residual degrees of freedom in the subsequent ANOVA were reduced by 1 to account for this adjustment (Underwood 1981).

Survivorship of Mya arenaria was significantly enhanced by the structure Rangia cuneata provided in the sediment (ANOVA and SNK tests; Table 3, Fig. 7). This enhancement was obtained whether $R$. cuneata was planted in bare sediment or in patches of widgeon grass, but survivorship was significantly greater where $R$. cuneata were in bare sediment (SNK tests; Fig. 7). The effect of widgeon grass on the value of $R$. cuneata as a refuge for $M$. arenaria was to cause a decrease in survivorship from 77 to $56 \%$ (Site 1) and 44 to $22 \%$ (Site 2 ) when vegetation occurred in plots with $R$. cuneata compared with plots containing only $R$. cuneata. As in the previous experiments in 1991, there was no significant increase in survivorship in patches of widgeon grass compared with bare sand (Fig. 7). The significant Site $\times$ Predator interaction (Table 3) was a result of significantly greater survivorship in Site 1 than Site 2 for all plots exposed to predators (Fig. 7).

\section{Expt 4: effects of Rangia cuneata and shell on Macoma balthica}

Survivorship of Macoma balthica in September 1992 was also significantly enhanced by the presence of Rangia cuneata material in the sediments, whether in the form of live clams, sham clams or separate shell valves (ANOVA and SNK tests; Table 3, Fig. 8). Survivorship was, however, significantly greater in the plots with dead $R$. cuneata valves than in plots with the live clams (Fig. 8). There was no significant difference in survivorship between plots with sham clams or shell valves. Survivorship in the bare sediment was less than $10 \%$ after only $7 \mathrm{~d}$ exposure to predation.

\section{DISCUSSION}

The principal epibenthic predators in the mesohaline sections of the Pamlico and Neuse estuaries are blue crabs Callinectes sapidus, mud crabs Panopeus spp.,

Table 2. Analysis of mean survivorship of Mya arenaria and Macoma balthica in 2 different Habitats (bare sediment and Ruppia maritima) after $7 d$ exposure at 2 Sites (Brown Creek and Luckens-South River) with treatments plus or minus Predators (data transformed to arcsine $\sqrt{\bar{X}} ; n=4$ plots). Significance as in Table 1

\begin{tabular}{|c|c|c|c|c|c|c|c|}
\hline \multirow{2}{*}{$\begin{array}{l}\text { Source of } \\
\text { variance }\end{array}$} & \multirow[b]{2}{*}{ df } & \multicolumn{3}{|c|}{ Mya arenaria } & \multicolumn{3}{|c|}{ Macoma balthica } \\
\hline & & MS & F & $\mathrm{p}$ & MS & $F$ & $\mathrm{p}$ \\
\hline Site (S) & 1 & 118.59 & 3.12 & ns & 57.41 & 1.25 & ns \\
\hline Predator $(P)$ & 1 & 24518.37 & 543.88 & $\cdot$ & 30149.06 & 1238.50 & $\cdots$ \\
\hline Habitat (H) & 1 & 4.74 & 1.29 & ns & 0.48 & 0.04 & ns \\
\hline $\mathrm{S} \times \mathrm{P}$ & 1 & 45.11 & 1.18 & ns & 24.32 & 0.53 & ns \\
\hline $\mathrm{S} \times \mathrm{H}$ & 1 & 3.63 & 0.10 & ns & 12.77 & 0.28 & ns \\
\hline $\mathrm{P} \times \mathrm{H}$ & 1 & 30.64 & 1.79 & ns & 7.55 & 0.03 & ns \\
\hline $\mathrm{S} \times \mathrm{P} \times \mathrm{H}$ & 1 & 17.11 & 0.45 & ns & 263.99 & 5.76 & $\cdot$ \\
\hline Residual & 24 & 38.06 & & & 45.81 & & \\
\hline
\end{tabular}



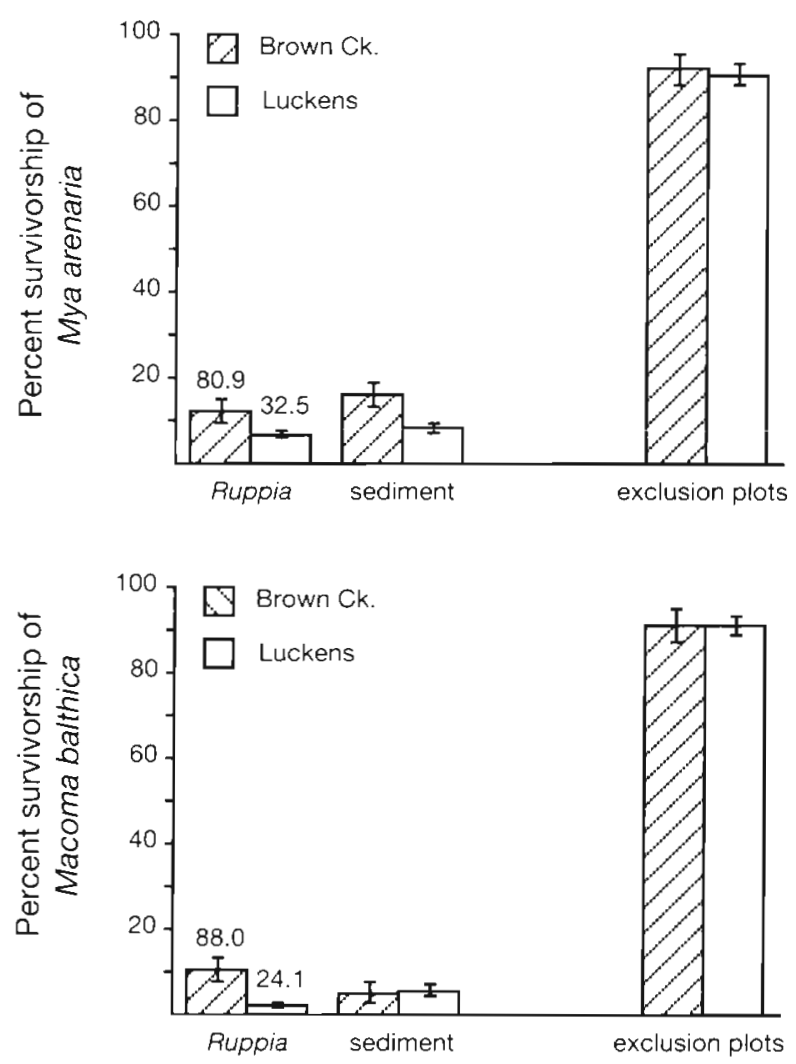

Fig. 6. Mean ( \pm SE) \% survivorship of Mya arenaria and Macoma balthica in plots of bare sediment and in different biomasses of seagrass Ruppia maritima in Brown Creek and Luckens, South River after 7 d predation in 1991 Means for Exclusion Plots are pooled from all predator-exclusion plots for that site because they were not significantly different from each other (SNK tests; $p=0.05$ ). Numbers above bars show mean dry weight $(\mathrm{g})$ of seagrass in plots at the end of the experiment

and sciaenid fishes such as spot Leiostomus xanthurus, croaker Micropogonias undulatus and pinfish Lagodon rhomboides (Peterson \& Skilleter unpubl., Skilleter unpubl.). While the fishes browse on clam siphons (Hines et al. 1990, Peterson \& Skilleter unpubl.) they do not consume whole clams, presumably because the clams reside too far down in the substratum. Mud crabs are common in the sediments in South River and Brown Creek. I never observed any larger than ca $25 \mathrm{~mm}$ width in the shallow sections of the rivers, although large ones may inhabit deeper waters. Mud crabs are able to capture postlarval lobsters buried in mud and eelgrass habitats (Barshaw \& Lavalli 1988) so it may be possible for large mud crabs to excavate and eat Macoma balthica and Mya arenaria. There are no data on this.

Blue crabs are extremely abundant in these waters and reach sizes greater than $200 \mathrm{~mm}$ in carapace width. They were frequently seen in the shallows around experimental plots and broken remains of shells were suggestive of predation by crabs. Blue crabs are the principal predator of Macoma balthica and Mya arenaria in Chesapeake Bay (Blundon \& Kennedy 1982a, Hines et al. 1990, Eggleston et al. 1992a) and it seems likely they are also important in Pamlico Sound. They are certainly significant predators of epifaunal and infaunal bivalves in more saline regions of North Carolina's estuaries (Lin 1989, Peterson 1990, Ambrose \& Irlandi 1992).

Macoma balthica and Mya arenaria both obtained a substantial refuge from predation by crabs when living amongst the large mactrid bivalve Rangia cuneata, although the extent of this protection varied from site to site for $M$. arenaria. At one site, over $75 \%$ of $M$. arenaria survived in plots with $R$. cuneata compared with less than $10 \%$ in bare sediment. At the other site, survivorship was only ca $30 \%$ in plots with $R$. cuneata but still significantly greater than in bare sand. At this second site, survivorship of $M$. balthica was also ca $30 \%$ in plots with $R$. cuneata compared with less than $10 \%$ in bare sand. This refuge was obtained in the presence of live or sham mactrids and also loose shell material, suggesting the mechanism relates to the presence of structure in the sediment (e.g. barriers to foraging predators) rather than a feature associated with living $R$. cuneata (e.g, an alternative prey for

Table 3. Analysis of mean survivorship of Mya arenaria or Macoma balthica in different Habitats (bare sediment, sediment +50 Rangia cuneata, sediment +50 sham $R$. cuneata, sediment +100 shell valves, Ruppia maritima, or $R$. maritima $+50 R$. cuneata) with treatments plus or minus Predators. For $M$. arenaria 2 Sites were randomly chosen in South River (data transformed to arcsine, $\bar{x}_{i} \mathrm{n}=3$ plots for each analysis see text for further details). Results for comparisons among treatments (SNK tests) are shown in Figs $7 \&$ \&. Significance as in Table 1

\begin{tabular}{|c|c|c|c|c|}
\hline Source of variance & $\mathrm{df}$ & MS & $F$ & $\mathrm{p}$ \\
\hline \multicolumn{5}{|l|}{ Mya arenaria } \\
\hline Site (S) & 1 & 829.72 & 31.52 & $\cdots$ \\
\hline Predator (P) & 1 & 23607.62 & 41.22 & ns \\
\hline Habitat $(\mathrm{H})$ & 3 & 841.19 & 18.99 & $\cdot$ \\
\hline $\mathrm{S} \times \mathrm{P}$ & 1 & 572.73 & 21.76 & $\cdots$ \\
\hline $\mathrm{S} \times \mathrm{H}$ & 3 & 44.30 & 1.68 & ns \\
\hline $\mathrm{P} \times \mathrm{H}$ & 3 & 1121.25 & 23.92 & $\cdot$ \\
\hline $\mathrm{S} \times \mathrm{P} \times \mathrm{H}$ & 3 & 46.88 & 1.78 & ns \\
\hline Residual & $31^{\mathrm{a}}$ & 26.33 & & \\
\hline \multicolumn{5}{|l|}{ Macoma balthica } \\
\hline Predator $(\mathrm{P})$ & 1 & 7793.21 & 331.50 & $\cdots$ \\
\hline Habitat $(\mathrm{H})$ & 3 & 484.06 & 20.59 & $\cdots$ \\
\hline $\mathrm{P} \times \mathrm{H}$ & 3 & 540.15 & 22.98 & $\cdots$ \\
\hline Residual & 16 & 23.51 & & \\
\hline \multicolumn{5}{|c|}{$\begin{array}{l}\text { d Loss of a single degree of freedom from ANOVA due to } \\
\text { replacement of } 1 \text { control plot with the mean of the other } \\
2 \text { replicates (see text for details) }\end{array}$} \\
\hline
\end{tabular}


Fig. 7. Mean ( \pm SE) \% survivorship of $M y a$ arenaria in plots of bare sediment, widgeon grass, widgeon grass +50 Rangia cuneata and sediment $+50 R$. cuneata at 2 sites in South River in 1992. Means for Exclusion Plots are pooled from all predator-exclusion plots for that site because they were not significantly different from each other (SNK tests; $\mathrm{p}=0.05$ ). Bars topped by the same letter are not significantly different from each other (SNK tests)
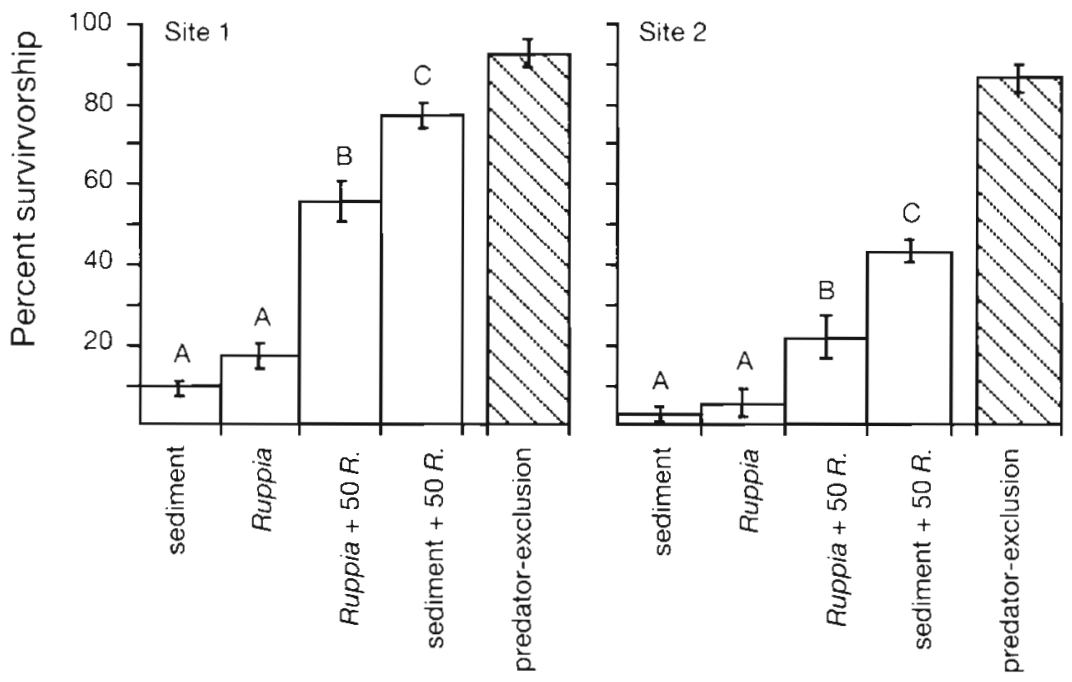

crabs, or movement by $R$. cuneata within the sediment). In fact, having live $R$. cuneata actually reduced survivorship compared with the dead shell material.

The importance of shell material in creating a partial refuge for the hard clam Mercenaria mercenaria from predation by blue crabs is well known (Castagna \& Kraeuter 1977, Arnold 1984, Gibbons \& Castagna 1985, Sponaugle \& Lawton 1990) and has been utilised in attempts to artificially increase fisheries yields of this commercially important species (Gibbons \& Castagna

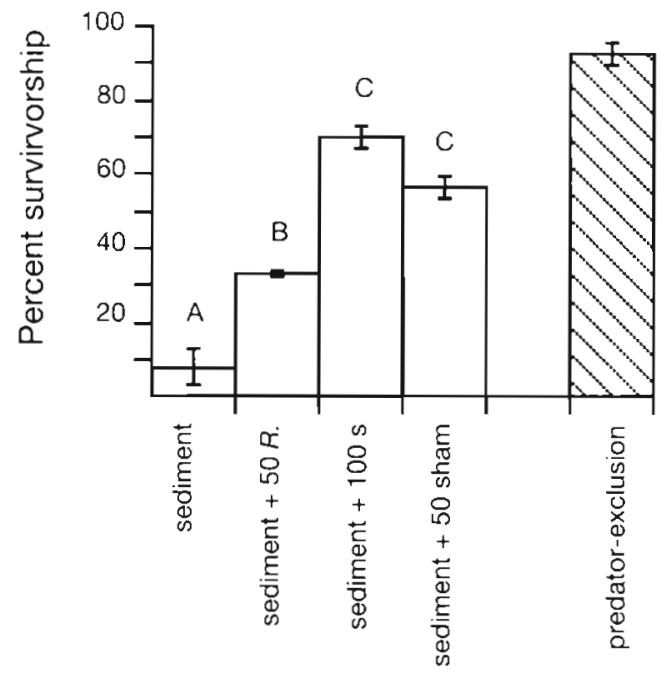

Fig. 8. Mean ( $\pm \mathrm{SE}$ ) \% survivorship of Macoma balthica in plots of bare sediment, sediment +50 Rangia cuneata, sediment +100 shell valves of $R$. cuneata and sediment +50 sham $R$. cuneata in South River in 1992. Mean for Exclusion Plots is pooled from all predator-exclusion plots because they were not significantly different from each other (SNK tests; $p=0.05$ ). Bars topped by the same letter are not significantly different from each other (SNK tests)
1985). Similarly, controlled planting of shell material and gravel has also been used to enhance fisheries production of Dungeness crab Cancer magister on the west coast of the United States (Dumbauld et al. 1993).

The results of my experiments indicate that shell material also allows localised persistence of relatively large densities of 2 deep-burrowing clams, Mya arenaria and Macoma balthica, in North Carolina estuaries. While these species are presently not commercially important in North Carolina, they do form a major part of the diet of blue crabs and sciaenid fishes (e.g. Currin 1984. Currin et al. 1984. Hines et al. 1990) which are extremely important components of the state's commercial and recreational fishery (e.g. Murray et al. 1991). The occurrence of refuges from predation for these clams may be an important reason for their persistence in Pamlico Sound despite seasonally intense predation and may also have important consequences for secondary production of some commercial species (such as crabs and fishes).

Attempts are currently under way to assess the viability of establishing a commercial fishery for Mya arenaria in North Carolina waters (C. H. Peterson pers. comm.). $M$. arenaria is considered a delicacy in the northeastern USA and there is potential for establishment of a new fishery in North Carolina if clams can be protected from intensive predation. Pilot experiments in Pamlico Sound indicated that rates of growth of M. arenaria were higher in North Carolina than in more northerly waters with clams reaching a marketable size within 12 mo compared with at least 2 yr in Massachusetts (Brousseau 1987, Peterson unpubl.). The protection afforded to $M$. arenaria by shell material may enable an economically viable fishery for these clams to be established in the state, providing an additional source of income for local fishing communi- 
ties. North Carolina Division of Marine Fisheries already has a large-scale programme of dumping shell material into Pamlico Sound to enhance natural settlement of oysters. Densities of $M$. arenaria within these shell piles appear to be significantly higher than in surrounding areas of bare sediment ( $R$. Herbert unpubl.). This programme could possibly be diversified to include planting of shell in shallow waters to allow the formation of 'Mya leases' in a similar fashion to the extensive hard clam leases in more saline sections of North Caroiina estuaries (Peterson 1990).

Sponaugle \& Lawton (1990) studied foraging behaviour in Callinectes sapidus and Ovalipes ocellatus and found that rates of predation on hard clams were significantiy reduced in sand/shell aggregates compared with just sand (see also Arnold 1984). Crabs spent more time foraging in the substratum containing shell but captured fewer prey, spending much of the time handling non-prey items and even attempting to 'open' shell and gravel fragments. Although done in the laboratory, these results may help explain the occurrence of a refuge for Mya arenaria and Macoma balthica in shells of Rangia cuneata. To reach these deep-burrowing clams, crabs would have to dig through the layers of $R$. cuneata or shell valves constantly testing fragments for suitability as prey. Between 2 and $10 \%$ of sham $R$. cuneata were broken open in treatment plots but none were split in predator-exclusion plots indicating that crabs had attempted to consume them. Blue crabs have been observed to open sham Mercenaria mercenaria and attempt to eat them in laboratory experiments (F. Micheli pers. comm.). If shell material reduces the relative foraging efficiency of crabs in the field, they may be induced to move to more profitable patches (e.g. Hassell 1978, Kacelnik \& Krebs 1986) accounting for the rapid disappearance of clams from sediments without any large fragments of shell.

There were 2 surprising results in these experiments. First, survivorship of clams was significantly reduced in patches containing both seagrass and Rangia cuneata compared with patches of only $R$. cuneata. Second, survivorship was significantly less in patches of live $R$. cuneata than in patches of 'sham' clams or equal numbers of shell valves.

Although the presence of widgeon grass in plots with Rangia cuneata increased above- and below-ground structural complexity compared with plots containing only the mactrids, survivorship of clams was less in the more complex patches of habitat. The large shells of the mactrids lost some of their ability to shelter the softshelled clams from predators with the addition of further heterogeneity from seagrasses. I offer 2 alternative possibilities to explain this unexpected result but note that they may not be mutually exclusive and may operate in concert.
First, the presence of subsurface rhizomes may reduce the depth to which clams are able to burrow into the substratum, hence leaving them more vulnerable to predation by blue crabs (e.g. Brenchley 1982). In unvegetated sediment, unhindered by rhizomes, Mya arenaria may have burrowed to greater depths thus avoiding predators. Deep burrowing has been postulated as an important refuge from blue crab predation for both $M$. arenaria and $M$. balthica (Blundon \& Kennedy 1982a, Hines \& Comtois 1985, Eggleston et al. 1992a). Although not specifically tested here, I feel this explanation is unlikely for several reasons. When I introduced the clams into plots, I forced a hole through the upper layers of the rhizomes and pushed the clams into that hole so they did not need to penetrate the material themselves. Also, clams in all predatorexclusion plots, vegetated and unvegetated, had usually buried themselves to the maximal depth available in these shallow sediments, just above the hard clay layer underlying the upper sediments. If this were also true in open plots, clams in unvegetated areas would not have been able to bury to greater depths than those in plots with widgeon grass and could not have obtained a partial and extra refuge from predators.

Second, the inclusion of seagrass in plots with Rangia cuneata not only involved an increase in overall habitat heterogeneity but also incorporated an additional and different type of habitat. The availability of this 'alternative' habitat may have changed the numbers and types of predators and/or alternative prey in these treatment plots, leading to difference in the rates of predation on the clams. For example, there are frequently greater numbers of epibenthic and infaunal invertebrates and fishes in seagrass beds than in nearby unvegetated habitats (reviewed by Orth et al. 1984) and many of these animals are alternative prey for blue crabs, which are opportunistic omnivores (e.g. Laughlin 1982, Hines et al. 1990). At least some predators are known to concentrate their attentions on patches of denser prey (Murdoch \& Oaten 1975. Hassell 1978) and will remain for some time in the vicinity of their most recent meal. Indeed, the aggregation of predators around patches with large densities of prey is thought to provide a partial refuge for prey in lessdense areas (Hassell 1978). Density-dependent foraging by blue crabs has been demonstrated in the laboratory (Lipcius \& Hines 1986, Mansour \& Lipcius 1991. Eggleston et al. 1992a). If blue crabs are attracted to areas with dense prey in the field (say, Ruppia beds) and forage there for greater periods of time than in nearby unvegetated patches, rates of encounter with clams are probably increased by chance alone, leading to decreased survivorship despite the protection afforded by shells of $R$. cuneata. Experimental studies which examine the behavioural responses of blue 
crabs and subsequent survivorship of prey as a function of prey density and the presence of alternative prey in the field are needed to test this hypothesis

Alternatively, there may be greater numbers of a particular predator inside patches of seagrass than in unvegetated sediments, again leading to increased rates of encounter between predators and prey. In particular, densities of juvenile blue crabs are often significantly greater inside seagrass beds (e.g. Orth \& van Montfrans 1987), a result of them obtaining a refuge from their own predators (Wilson et al. 1987 , 1990). When blue crabs are restricted in the range of habitats in which they can forage (at least in the laboratory), they are able to extract and consume prey despite the presence of material which otherwise provides a significant refuge. Detailed sampling in different habitats in the Pamlico estuarine system would at least provide a partial test of this model.

The possibility that blue crabs concentrate their foraging effort in patches with increased abundance of prey may also offer an explanation for the second unanticipated result: decreased survivorship of Macoma balthica in patches with live Rangia cuneata than in patches with sham clams or shell valves (Fig. 8). $R$. cuneata lives close to the surface of the substratum and its large valves often protrude slightly into the water column (pers, obs.), an attractive source of potential prey for crabs. $R$. cuneata are themselves relatively immune to predation by blue crabs (Blundon \& Kennedy 1982b) but their presence may indirectly increase mortality of other infauna.

Neither Macoma balthica nor Mya arenaria obtained any refuge from predation by living in beds of widgeon grass Ruppia maritima. Survivorship in plots with seagrass was less than $25 \%$ after only $7 \mathrm{~d}$ exposure to predators and was never significantly greater than nearby unvegetated plots. This seems contradictory to the results of previous studies in which the presence of seagrass reduced rates of predation on a variety of different faunal groups (e.g. Coen et al. 1981, Heck \& Thoman 1981, Peterson 1982, Summerson \& Peterson 1984, Leber 1985, but see Barshaw \& Lavalli 1988 and Eggleston et al. 1992b for counter-examples).

Characteristics of seagrasses that act to mitigate predation include the density of shoots and overall plant biomass, leaf morphology and thickness and the thickness of the rhizome mat (Orth et al. 1984). Variation in each of these features may explain why Ruppia maritima did not provide any protection from foraging predators for Macoma balthica or Mya arenaria in my experiments. In nearshore shallow areas of Pamlico Sound where these experiments were done, $R$. maritima only reaches a relatively small biomass $\left(<80 \mathrm{~g} \mathrm{~m}^{-2}\right.$; pers. obs.). This is substantially less than the biomass of grass found to provide a refuge from predation for infauna (> $1900 \mathrm{~g} \mathrm{~m}^{-2}$; Peterson 1982) or epibenthic fauna (Wilson et al. 1987, 1990) in other studies. It may be that the sparse nature of the beds of seagrass in shallow sections of mesohaline Pamlico Sound is insufficient to hinder the activities of abundant predators such as blue crabs. In deeper parts of the river, however, $R$. maritima has a much greater biomass and can extend through 2 to $3 \mathrm{~m}$ of the water column reaching the surface (e.g. deeper portions of Big Creek). In these deeper areas the value of $R$. maritima as a protective habitat for infaunal invertebrates may be much greater than was shown here. Additionally, the blades of $R$. maritima are thread-like whereas in seagrasses such as Zostera they are strap-like with much greater surface area (Humphries et al. 1992). This may mean $R$. maritima offers less resistance than other species of seagrass to movement of predators foraging through the vegetation. There have been so few studies examining the role of Ruppia beds in estuarine systems that it is difficult to speculate further on other possible explanations for the observed results.

Finally, the refuge obtained by Mya arenaria and Macoma balthica when living among Rangia cuneata is a striking example of an associational defence between potentially competing species (Hay 1986). There is an obvious and marked benefit to $M$. arenaria and $M$. balthica living in the company of the larger bivalves in the form of greatly increased survivorship even though they may compete with $R$. cuneata for resources such as space (e.g. Peterson \& Andre 1980) or suspended food (Skilleter \& Peterson unpubl.). As discussed above, the presence of $R$. cuneata provides sufficient structure within the sediments to impede the access of blue crabs to the deeper-burrowing and more vulnerable $M$. arenaria and $M$. balthica. Similar advantages of 'group living' have been proposed to explain greater survivorship of epibenthic mussels living in the middle of large clumps compared with solitary animals or those living on the edge of aggregations (e.g. Bertness \& Grosholz 1985, Okamura 1986).

Examples of such mutualistic biological interactions, although apparently widespread, have not previously been incorporated into synthetic models for softsediment systems (Dayton \& Oliver 1980). Recently, however, Peterson \& Black (1993) have argued that such positive interactions may be extremely important in structuring assemblages of infauna and have encouraged the development of new population theory to incorporate such interactions.

In conclusion, I have shown that 2 species of infaunal clam, both vulnerable to blue crab predation and suffering extensive mortality in vegetated and unvegetated sand and mud habitats, gain an unusual refuge by living among a large suspension-feeding bivalve, Rangia cuneata. This refuge appears to be primarily a 
function of the occupation of space within the sediments by $R$. cuneata because 'sham' clams and single valves (shell material) provided a similar refuge from predation. Encounter rates by crabs with Mya arenaria and Macoma balthica may be reduced because the crabs spend greater amounts of time handling nonfood items, making patches with shell less profitable for foraging. Future experiments examining predator behaviour in different habitats, especially in response to availability of alternative prey and the effects of risk of predation on predator behaviour, may help extend some of the results described here to produce a more synthetic understanding of the roles of refuges in aquatic systems.

Acknowledgements. This work was supported by NSF Biological Oceanography Program Grant OCE-862010 and by a Sea Grant (NOAA) from the University of North Carolina Sea Grant College Program to Charles H. Peterson. I thank Beth Irlandi, Lisa Kellogg, Karen Lally, Beth Orlando, Joe Purifoy, Fiorenza Micheli, Glenn Safrit, Kate Skilleter, Joel Speicher and Pam Wyrick for help in the field at various times during my stay in North Carolina. Joe Huber kindly provided Mya from his hatchery in Atlantic, NC, and Hal Summerson sorted and maintained them in upwelling tanks at the Institute of Marine Sciences in 1991. Hal Summerson also collected some of the abundance data for Mya and Macoma and initially pointed out the presence of 'refuges' for Macoma among shell material. Kate Skilleter made the sham Rangia. Gee Chapman, Beth Irlandi, Pete Peterson, Kate Skilleter and Don Morrisey provided helpful comments on an early draft of this manuscript.

\section{LITERATURE CITED}

Ambrose, W. G. Jr, Irlandi, E. A. (1992). Height of attachment on seagrass leads to trade-off between growth and survival in the bay scallop Argopecten irradians. Mar. Ecol Prog. Ser. 90: 45-51

Arnold, W. S. (1984). The effect of prey size, predator size, and sediment composition on the role of predation of the blue crab, Callinectes sapidus Rathbun, on the hard clam, Mercenaria mercenaria (Linné). J. exp. mar. Biol. Ecol. 80 : $207-219$

Barshaw, D. E., Lavalli, K. L. (1988). Predation upon postlarval lobsters Homarus americanus by cunners Tautolabrus adspersus and mud crabs Neopanope sayi on three different substrates: eelgrass, mud and rocks. Mar. Ecol. Prog. Ser. 48: 119-123

Bernstein, B. B., Jung, N. (1979). Selective pressures and coevolution in a kelp canopy community in southern California. Ecol. Monogr. 49: 335-355

Bertness, M. D., Grosholz, E. (1985). Population dynamics of the ribbed mussel, Geukensia demissa - the costs and benefits of an aggregated distribution. Oecologia 67: 192-204

Blundon, J. A., Kennedy, V. S. (1982a). Refuges for infaunal bivalves from the blue crab, Callinectes sapidus, predation in Chesapeake Bay. J. exp. Mar. Biol. Ecol. 65: 67-82

Blundon, J. A., Kennedy, V. S. (1982b). Mechanical and behavioural aspects of the blue crab, Callinectes sapidus (Rathbun), predation on Chesapeake Bay bivalves. J. exp. mar. Biol. Ecol. 65: 47-66

Brenchley, G. A. (1982). Mechanisms of spatial competition in marine soft-bottom communities. J. exp. mar. Biol. Ecol. 60: $17-33$

Brousseau, D. J. (1987). A comparative study of the reproductive cycle of the soft-shell clam Mya arenaria in Long Island Sound. J. Shellfish Res. 6: 7-16

Capehart, A. A., Hackney, C. T. (1989). The potential role of roots and rhizomes in structuring salt-marsh benthic communities. Estuaries 12: 119-122

Castagna, M., Kraeuter, J. N. (1977). Mercenaria culture using stone aggregate for predator protection. Proc. natl Shellfish. Ass. 67: 1-6

Caswell, H. (1978). Predator-mediated coexistence: a nonequilibrium model. Am. Nat. 112: 127-154

Coen, L. D., Heck, K. L., Abele, L. G. (1981). Experiments on competition and predation among shrimps of seagrass meadows. Ecology 62: 1484-1493

Connell, J. H. (1970). A predator-prey system in the marine intertidal region. I. Balanus glandula and several predatory species of Thais. Ecol. Monogr. 40:49-78

Crowder, L. B., Cooper, W. E. (1982). Habitat structural complexity and the interaction between bluegills and their prey. Ecology 65: 1802-1813

Currin, B. M. (1984). Food habits and food consumption of juvenile spot, Leiostomus xanthurus, and croaker, Micropogonias undulatus, in their nursery areas. North Carolina State University, Raleigh

Currin, B. M., Reed, J. P., Miller, J. M. (1984). Growth, production, food consumption, and mortality of juvenile spot and croaker: a comparison of tidal and nontidal nursery areas. Estuaries 7: 451-459

Dayton, P. K. (1985). Ecology of kelp communities. A. Rev. Ecol. Syst. 16: 215-246

Dayton, P. K., Oliver, J. S. (1980). An evaluation of experimental analyses and community patterns in benthic marine environments. In: Tenore, K. R., Coull, B. C. (eds.) Marine benthic dynamics. University of South Carolina Press, Columbia, p. 93-120

Dumbauld, B. R., Armstrong, D. A., McDonald, T. L. (1993). Use of oyster shell to enhance intertidal habitat and mitigate loss of Dungeness crab (Cancer magister) caused by dredging. Can. J. Fish. Aquat. Sci. 50: 381-390

Ebeling, A. W., Laur, D. R. (1985). The influence of plant cover on surf perch abundance at an offshore temperate reef. Environ. Biol. Fish. 12: 169-179

Eggleston, D. B., Lipcius, R. N., Hines, A. H. (1992a). Densitydependent predation by blue crabs upon infaunal clam species with contrasting distribution and abundance patterns. Mar. Ecol. Prog. Ser. 85: 55-68

Eggleston, D. B., Lipcius, R. N., Miller, D. L. (1992b). Artificial shells and survival of juvenile Caribbean spiny lobster Panulirus argus - spatial, habitat, and lobster size effects. Fish. Bull. 90:691-702

Everett, R. A., Ruiz, G. M. (1993). Coarse woody debris as a refuge from predation in aquatic communities - an experimental test. Oecologia 93: 475-486

Ferguson, R. L., Rivera, J. A., Wood, L. L. (1988). Submerged aquatic vegetation in the Albermarle-Pamlico estuarine system. National Marine Fisheries Service, NOAA, Beaufort, NC, p. 1-68

Fernandez, M., Iribarne, O., Armstrong, D. (1993). Habitat selection by young-of-the-year dungeness crab Cancer magister and predation risk in intertidal habitats. Mar. Ecol. Prog. Ser. 92: 171-178

Gibbons, M. C., Castagna, M. (1985). Biological control of production by crabs in bottom cultures of hard clams using a combination of crushed stone aggregate, toadfish, and cages. Aquaculture 47: 101-104. 
Gilinsky, E. (1984). The role of fish predation and spatial heterogeneity in determining benthic community structure. Ecology 65: 455-468

Gotceitas, V., Colgan, P. (1989). Predator foraging success and habitat complexity: quantitative test of the threshold hypothesis. Oecologia 80: 158-166

Hassell, M. P. (1978). The dynamics of arthropod predatorprey systems. Monographs in population biology. Princeton University Press, Princeton, NJ

Hay, M. E. (1986). Associational plant defenses and the maintenance of species diversity: turning competitors into accomplices. Am. Nat. 128: 617-641

Heck, K. L., Thoman, T A. (1981). Experiments on predatorprey interactions in vegetated aquatic habitats. J. exp. mar. Biol. Ecol. 53: 573-596

Hicks, G. R. F., Coull, B. C. (1983). The ecology of marine meiobenthic copepods. Oceanogr. mar. Biol. A. Rev, 21. $67-175$

Hines, A. H., Comtois, K. L. (1985). Vertical distribution of estuarine infauna in sediments in a subestuary of central Chesapeake Bay. Estuaries 8: 296-304

Hines, A. H., Haddon, A. M., Wiechert, L. A. (1990). Guild structure and foraging impact of blue crabs and epibenthic fish in a subestuary of Chesapeake Bay. Mar. Ecol. Prog. Ser. 67: 105-126

Homziak, J. (1985). Does succession occur in estuarine soft substrates? Seasonal patterns of colonization and mechanisms of species replacement in experimentally defaunated sediments. University of North Carolina at Chapel Hill, Chapel Hill

Huffaker, C. B. (1958). Experimental studies on predation: dispersion factors and predator-prey oscillations. Hilgardia $27: 343-383$

Humphries, P., Potter, I. C., Loneragan, N. R. (1992). The fish community in the shallows of a temperate Australian estuary - relationships with the aquatic macrophyte Ruppia megacarpa and environmental variables. Estuar. coast. Shelf Sci. 34: 325-346

Irlandi, E. A., Peterson, C. H. (1991). Modification of animal habitat by large plants - mechanisms by which seagrasses influence clam growth. Oecologia 87: 307-318

Kacelnik, A., Krebs, J. R. (1986). Learning to exploit patchily distributed food. In: Sibly, R. M., Smith, R. H. (eds.) Behavioural ecology: ecological consequences of adaptive behaviour. Blackwell Scientific Publications, Oxford, p. 189-205

Kohn, A. J., Leviten, P. J. (1976). Effect of habitat complexity on population density and species richness in tropical intertidal predatory gastropod assemblages. Oecologia 25: $199-210$

Laughlin, R. A. (1982). Feeding habits of the blue crab, Callinectes sapidus Rathbun, in the Apalachicola Estuary, Florida. Bull. mar. Sci. 32: 807-822

Leber, K. M. (1985). The influence of predatory decapods, refuge, and microhabitat selection on seagrass communities. Ecology 66: 1951-1964

Lin, J. (1989). Influence of location in a salt-marsh on survivorship of ribbed mussels. Mar. Ecol. Prog. Ser. 56: 105-110

Lipcius, R. N., Hines, A. H. (1986). Variable functional responses of a marine predator in dissimilar homogenous microhabitats. Ecology 67: 1361-1371

Lubchenco, J., Menge, B. A., Garrity, S. D., Lubchenco, P. J., Ashkenas, L. R., Gaines, S. D., Emlet, R., Lucas, J., Strauss, S. (1984). Structure, persistence, and the role of consumers in a tropical rocky intertidal community (Taboguilla Island, Bay of Panama). J. exp. mar. Biol. Ecol. 78: $23-74$
Mansour, R. A., Lipcius, R. N. (1991). Density-dependent foraging and mutual interference in blue crabs preying upon infaunal clams. Mar. Ecol. Prog. Ser. 72: 239-246

Marinelli, R. L., Coull, B. C. (1987). Structural complexity and juvenile fish predation on meiobenthos: an experimental approach. J. exp. mar. Biol. Ecol. 108: 67-81

McGuinness, K. A., Underwood, A. J. (1986). Habitat structure and the nature of communities on intertidal boulders. J. exp. mar. Biol. Ecol. 104: 97-123

Minello, T J., Zimmerman, R. J. (1983). Fish predation on juvenile brown shrimp, Penaeus aztecus lves: the effect of simulated Spartina structure on predation rates. J. exp. mar. Biol. Ecol. 72: 211-231

Murdoch, W. W., Oaten, A. (1975). Predation and population stability. Adv. Ecol. Res. 9: 1-131

Murray, J D., Bahen, J. J., Rulifson, R. A. (1991). Management considerations for by-catch in the North Carolina and southeast shrimp fishery. Fisheries 17: 21-26

Okamura, B. (1986). Group living and the effects of spatial position in aggregations of Mytilus edulis. Oecologia 69: $341-347$

Orth, R. J., Heck, K. L., van Montfrans, J. V. (1984). Faunal communities in seagrass beds: a review of the influence of plant structure and prey characteristics on predator-prey relationships. Estuaries $7: 339-350$

Orth, R. J., van Montfrans, J. (1987). Utilization of a seagrass meadow and tidal marsh creek by blue crabs Callinectes sapidus. I. Seasonal and annual variations in abundance with emphasis on post-settlement juveniles. Mar. Ecol. Prog. Ser. 41: 283-294

Peterson, C. H. (1982). Clam predation by whelks (Busycon spp.): experimental tests of the importance of prey size, prey density, and seagrass cover. Mar. Biol. 66: 159-170

Peterson, C. H. (1990). On the role of ecological experimentation in resource management: managing fisheries through mechanistic understanding of predator feeding behaviour. In: Hughes, R. N. (ed.) Behavioural mechanisms of food selection. NATO ASI Series Vol. G20. Springer-Verlag, Berlin, p. 821-846

Peterson, C. H., Andre, S. V. (1980). An experimental analysis of interspecific competition among marine filter feeders in a soft-bottom environment. Ecology 61: 129-139

Peterson, C. H., Black, R. (1993). Experimental tests of the advantages and disadvantages of high density for two coexisting cockles in a Southern Ocean lagoon. J. Anim. Ecol. 62: 614-633

Reise, K. (1977). Predation pressure and community structure of an intertidal soft-bottom fauna. In: Keegan, B. F., Credign, P. O., Boaden, P. J. S. (eds.) Biology of benthic organisms. Pergamon Press, New York, p. 513-519

Reise, K. (1978). Experiments on epibenthic predation in the Wadden Sea. Helgoländer wiss. Meeresunters. 31: 55-101

Savino, J. F., Stein, R. A. (1982). Predator-prey interaction between largemouth bass and bluegills as influenced by simulated, submersed vegetation. Trans. Am. Fish. Soc. 111: 255-266

Sponaugle, S., Lawton, P. (1990). Portunid crab predation on juvenile hard clams - effects of substrate type and prey density. Mar. Ecol. Prog. Ser. 67: 43-54

Stein, R. A., Magnuson, J. J. (1976). Behavioral response of crayfish to a fish predator. Ecology 57: 751-761

Stoner, A. W. (1982). The influence of benthic macrophytes on the foraging behaviour of pinfish, Lagodon rhomboides (Linnaeus). J. exp. mar. Biol. Ecol. 58: 271-284

Suchanek, T H. (1978). The ecology of Mytilus edulis L. in exposed rocky intertidal communities. J. exp. mar. Biol. Ecol. 31: 537-551 
Summerson, H. C., Peterson, C. H. (1984). Role of predation in organising benthic communities of a temperate-zone seagrass bed. Mar. Ecol. Prog. Ser. 15: 63-77

Tenore, K. R. (1972). Macrobenthos of the Pamlico river estuary, North Carolina. Ecol. Monogr. 40: 51-69

Underwood, A. J. (1981). Techniques of analysis of variance in experimental marine biology and ecology. Oceanogr. mar. Biol. A. Rev. 19: 513-605

Vince, S., Valiela, I., Backus, N. (1976). Predation by the salt marsh killifish, Fundulus heteroclitus (L.) in relation to prey size and habitat structure: consequences for prey distribution and abundance. J. exp. mar. Biol. Ecol. 23: $255-266$

This article was presented by A.J. Underwood (Senior Editorial Advisor), Sydney, Australia
Virnstein, R. W. (1977). The importance of predation by crabs and fishes on benthic infauna in Chesapeake Bay. Ecology 58: $1199-1217$

Wilson, K. A., Able, K. W., Heck, K. L. (1990). Predation rates on juvenile blue crabs in estuarine nursery habitats: evidence for the importance of macroalgae (Ulva lactuca). Mar. Ecol. Prog. Ser. 58: 243-251

Wilson, K. A., Heck, K. L. Jr, Able, K. W. (1987). Juvenile blue crab Callinectes sapidus survival: an evaluation of eelgrass, Zostera marina, as refuge. Fish. Bull. 85: 53-58

Woodin, S. A. (1978). Refuges, disturbance, and community structure: a marine soft-bottom example. Ecology 59: $274-284$

Manuscript first received: September 23, 1993

Revised version accepted: February 14, 1994 